\title{
An Integrated Strategy for the Proactive Management of Grapevine Trunk Disease Pathogen Infections in Grapevine Nurseries
}

\author{
F. Halleen ${ }^{1,2 *}$, P.H. Fourie ${ }^{2,3}$ \\ (1) ARC Infruitec-Nietvoorbij (The Fruit, Vine and Wine Institute of the Agricultural Research Council), Private Bag X5026, \\ Stellenbosch, 7599, South Africa \\ (2) Department of Plant Pathology, Stellenbosch University, Private Bag X1, Matieland, 7602, South Africa \\ (3) Citrus Research International, P.O. Box 2945, Uitenhage, 6230, South Africa
}

Submitted for publication: November 2015

Accepted for publication: May 2016

Key words: Phaeomoniella chlamydospora, Phaeoacremonium, Dactylonectria, Ilyonectria, Campylocarpon, Botryosphaeriaceae, Pleurostomophora richardsiae, Trichoderma

\begin{abstract}
The aim of this study was to compare 11 treatment regimes (TR) in grapevine nurseries in order to eradicate trunk pathogens. Grapevine propagation material was subjected to treatments before cold storage, before and after grafting, before planting and after uprooting. Isolations were made from roots, rootstocks and graft unions of uprooted vines. None of the treatments consistently affected the number of certifiable vines produced. TR 1 (benomyl), TR 3 (Sporekill) and TR 4 (Trichoflow) increased root mass. Phaeomoniella chlamydospora was the most frequently isolated pathogen from all plant parts. In general, TR 2, 7, 9 and 11 caused the lowest occurrence of Phaeomoniella. TR 9 consistently reduced the incidence of Phaeoacremonium. Pleurostomophora richardsiae occurred most frequently in graft unions, but treatments were too inconsistent to draw meaningful conclusions. TR 7 (hot water treatment (HWT) of uprooted grapevines) consistently reduced incidences of black foot disease (BFD) pathogens. The highest incidence of Botryosphaeriaceae occurred in graft unions, but all treatments significantly reduced infections. The colonisation of rootstocks and graft unions by Trichoderma was significantly better with TR 4 (Trichoflow). The other Trichoderma treatments (TR 9, 10 and 11) differed from the control treatment only in the graft unions. This is a first report of an integrated strategy covering all the phases of the propagation process, from the moment the nursery receives the propagation material until the dormant vines are removed. TR 9 is recommended for use in nurseries, although HWT of dormant vines is recommended to eradicate BFD pathogens. Benomyl can be replaced by carbendazim when benomyl is no longer available.
\end{abstract}

\section{INTRODUCTION}

Trunk disease pathogens of economic importance in grapevine nurseries include Phaeomoniella chlamydospora (W. Gams, Crous, M.J. Wingf. \& Mugnai) Crous \& W. Gams and Phaeoacremonium species that cause Petri disease (Halleen et al., 2003; Mostert et al., 2006a), as well as species within the Botryosphaeriaceae family that cause wood necrosis and dieback (Van Niekerk et al., 2004; 2006; 2010). Propagation material taken from apparently healthy mother vines can already be infected by these pathogens prior to grafting (Fourie \& Halleen, 2002; Halleen et al., 2003; Aroca et al., 2010) or become infected during the different nursery processes, mainly through the large number of wounds made (Halleen et al., 2003; Retief et al., 2006; Aroca et al., 2010; Gramaje \& Armengol, 2011; Agustí-Brisach et al., 2013). Pleurostomophora richardsiae (Nannf.) L. Mostert, W. Gams \& Crous, often found in graft unions of nursery vines (Halleen et al., 2003) and diseased vines (Halleen
\& Groenewald, 2005; Carlucci et al., 2015), has also been shown to be pathogenic towards grapevines (Halleen et al., 2007a). Trunk disease pathogens, either individually or collectively, can be responsible for graft failure (Khan et al., 2000; Sparapano et al., 2001; Wallace et al., 2003), ultimately contributing to low take percentages in nurseries. Dactylonectria, Ilyonectria and Campylocarpon species, causal organisms of black foot disease (BFD) (Scheck et al., 1998a; 1998b; Halleen et al., 2004; 2005; 2006; Lombard et al., 2014), can infect graftlings from infected soil soon after being planted in nurseries (Halleen et al., 2003). Furthermore, these early mother vine or nursery infections could remain latent until the vines are exposed to predisposing stress and/or conditions favourable for disease development once planted out in a vineyard (Ferreira et al., 1999; Van Niekerk et al., 2011).

In the past, standard practice in South African grapevine

*Corresponding author: E-mail address: halleenf@arc.agric.za

Acknowledgements: The authors would like to thank the ARC Infruitec-Nietvoorbij and Winetech, for financial support (Project WW06/33), and Zane Sedeman, Carine Vermeulen and Julia Marais, for technical assistance 
nurseries aimed at limiting superficial fungal growth on propagation material in cold storage and callus boxes included drench-treating propagation material with contact fungicides such a captan, iprodione, 8-hydroxyquinoline sulphate, procymidone and triadimefon (Fourie \& Halleen, 2004a). However, these fungicides were found to be moderately or poorly effective in reducing germination and mycelial growth of trunk disease pathogens such as $\mathrm{Pa}$. chlamydospora (Jaspers, 2001), species in Botryosphaeriaceae (Bester et al., 2007), Dactylonectria, Ilyonectria and Campylocarpon (Halleen et al., 2007b). Furthermore, the excessive amount of chemicals needed, e.g. captan, which is used at five times the registered dosage recommended for grapevine, is definitely not an environmentally friendly practice. But still, the production of healthy, pathogen-free grapevines is of cardinal importance to the grapevine industry. The treatment of hydration water with benomyl, and to some extent with Trichoderma harzianum-containing products, in which rootstock material is drenched before grafting, reduces the occurrence of Petri disease pathogens, whilst HWT of rootstocks (at $50^{\circ} \mathrm{C}$ for $30 \mathrm{~min}$ ) prior to grafting significantly reduced their occurrence (Fourie \& Halleen, 2004a). The treatment of hydration water with benomyl, didecyldimethylammonium chloride (Sporekill) and captan, in which rootstock and scion propagation material were drenched before cold storage, before grafting and prior to planting (repeated treatments), significantly reduced the incidences of trunk disease pathogens, while products containing Trichoderma harzianum were inconsistent (Fourie \& Halleen, 2006a). Repeated treatments at various stages throughout the propagation process therefore seem to be more effective in reducing pathogen occurrence. However, black foot disease pathogens can still infect these plants once they have been planted in nursery soils, and therefore pre-planting treatments must be complemented by treatments during the growing season, or once uplifted. Previous studies with Trichoderma-containing products in nurseries highlighted the growth-stimulating effects of Trichoderma (dipping grafting material, soil amendments prior to planting and soil drenches during the growing season), possibly producing stronger nursery vines that are less affected by replant stress and latent infections (Fourie et al., 2001). Furthermore, Trichoderma also has a direct effect on pathogens through competition, antibiosis, parasitism, etc. (Kotze et al., 2011; Mutawila et al., 2011). Unfortunately, the effect on Petri and BFD pathogens was either inconsistent or not significant (Fourie et al., 2001; Halleen et al., 2007b). The only treatment thus far found to be effective against BFD appears to be HWT of the dormant nursery vines once uplifted (Halleen et al., 2007b).

Although these studies gave significant insight into the presence of grapevine trunk disease-causing pathogens in propagation material, and critical stages in the propagation process could be identified, they focused only on the treatment of rootstock material at one specific period (Fourie \& Halleen, 2004a), or if repeat treatments of rootstock and scion material were investigated, the same product was used throughout the various stages (Fourie \& Halleen, 2006a). HWT prior to grafting was only investigated with rootstocks, and also not in combination with other treatments (Fourie \&
Halleen, 2004a). Benomyl proved to be the most effective treatment, since it was the most consistent. The aim of this project was to formulate and evaluate an integrated strategy for the proactive management of grapevine trunk diseases in nurseries. Various strategies, including chemical, biological and physical treatments, were investigated, with a special emphasis on environmentally safe alternatives. Benomyl is no longer available in most countries, and an effective replacement is required. Nursery trials were conducted in which different treatment regimes, divided into three categories according to their environmentally safe status, were compared with each other.

\section{MATERIALS AND METHODS \\ Grapevine material}

In June 2006 and 2007, 101-14 Mgt (clone AA219A) rootstock cuttings were obtained from a certified mother block. The mother block was selected on the basis of its relatively high incidence of Petri disease pathogens, which had been determined in previous studies (Fourie \& Halleen, 2004b). Shiraz (clone SH5C) scion cuttings were also obtained from a certified mother block during July 2006 and 2007.

\section{Treatments}

The treatments were set up as treatment regimes (TRs), with a single TR comprising the same treatment, or an integration of various treatments, being applied at various times during the propagation process. The treatments were applied as drenches before cold storage, before and after grafting, and before planting, as well as HWT of dormant nursery vines after uprooting (eight months after planting). The products included benomyl (Demeter 500WP, Volcano Agrosciences Pty Ltd., South Africa; 100 g/100 L water), carbendazim (Knowin 500SC, Plaaskem, South Africa; $100 \mathrm{ml} / 100 \mathrm{~L}$ water), didecyldimethylammonium chloride (Sporekill, ICA International Chemicals Pty. Ltd., Stellenbosch, South Africa; $150 \mathrm{ml} / 100 \mathrm{~L}$ water), Trichoflow-T ${ }^{\mathrm{TM}}$ (selected strains of Trichoderma harzianum, Agrimm Technologies Ltd., Christchurch, New Zealand; 2 g/L water) and chlorine dioxide (Oxine, Agri-Sense, Wellington, South Africa; $\mathrm{CLO}_{2}$ at $10 \mathrm{ppm}$ as recommended by the manufacturer). The same untreated tap water used by the commercial nursery was used as control treatment.

The propagation procedures followed by most South African nurseries have been explained by Fourie and Halleen (2006a; 2006b). In this study, cuttings were hand-grafted and subjected to a cold callus regime. The duration of drench treatments was adjusted as follows: rootstock and scion cuttings (400 per treatment regime) were drenched for $1 \mathrm{~h}, 30$ $\mathrm{min}, 1 \mathrm{~min}$ and $10 \mathrm{~min}$, respectively, in 50 litre suspensions of the fungicides, Trichoderma, $\mathrm{CLO}_{2}$-treated water or tap water prior to cold storage, before and after grafting and before planting (Table 1). HWT $\left(30 \mathrm{~min}\right.$ at $50^{\circ} \mathrm{C}$, followed by a 30 min cool-down period in tap water) of the rootstock and scion cuttings was included in three TRs, as a single treatment in TR 6, or combined with other treatments in the integrated TRs 9 and 11. In TR 9 and 11, the HWT $30 \mathrm{~min}$ cool-down period was done in Sporekill-amended water. TR 7 was subjected to HWT of dormant vines only $\left(30 \mathrm{~min}\right.$ at $50^{\circ} \mathrm{C}$, followed by $30 \mathrm{~min}$ in cold water). A summary of all the TRs, 
TABLE 1

Summary of the treatment regimes explaining the time and duration of each treatment.

\begin{tabular}{|c|c|c|c|c|c|c|}
\hline \multirow[b]{2}{*}{$\begin{array}{l}\text { Treatment } \\
\text { regime }\end{array}$} & \multicolumn{6}{|c|}{ Time and duration of application } \\
\hline & $\begin{array}{l}\text { Before cold } \\
\text { storage }(1 \mathrm{~h})\end{array}$ & $\begin{array}{l}\text { HWT before } \\
\text { grafting } \\
\left(30 \mathrm{~min} ; 50^{\circ} \mathrm{C}\right)\end{array}$ & $\begin{array}{l}\text { Before } \\
\text { grafting } \\
(30 \mathrm{~min})\end{array}$ & $\begin{array}{l}\text { After grafting } \\
(1 \mathrm{~min})\end{array}$ & $\begin{array}{l}\text { Before } \\
\text { planting } \\
(10 \mathrm{~min})\end{array}$ & $\begin{array}{l}\text { After uprooting } \\
\left(30 \mathrm{~min} ; 50^{\circ} \mathrm{C}\right)\end{array}$ \\
\hline 1. Benomyl & $\checkmark$ & $x$ & $\checkmark$ & $\checkmark$ & $\checkmark$ & $x$ \\
\hline 2. Carbendazim & $\checkmark$ & $x$ & $\checkmark$ & $\checkmark$ & $\checkmark$ & $x$ \\
\hline 3. Sporekill & $\checkmark$ & $x$ & $\checkmark$ & $\checkmark$ & $\checkmark$ & $x$ \\
\hline 4. Trichoflow & $\checkmark$ & $x$ & $\checkmark$ & $\checkmark$ & $\checkmark$ & $x$ \\
\hline 5. $\mathrm{CLO}_{2}$ & $\checkmark$ & $x$ & $\checkmark$ & $\checkmark$ & $\checkmark$ & $x$ \\
\hline 6. HWT (prior to grafting) & $x$ & $\checkmark$ & $x$ & $x$ & $x$ & $x$ \\
\hline 7. HWT (dormant vines) & $x$ & $x$ & $x$ & $x$ & $x$ & HWT \\
\hline 8. Control & $x$ & $x$ & $x$ & $x$ & $x$ & $x$ \\
\hline 9. Integrated & Benomyl & $\checkmark$ & Sporekill & Trichoflow & Trichoflow & $x$ \\
\hline 10. Integrated & Benomyl & $x$ & Sporekill & Trichoflow & Trichoflow & $x$ \\
\hline 11. Integrated & Benomyl & $\checkmark$ & Sporekill & No wax. Trichoflow & Trichoflow & $x$ \\
\hline
\end{tabular}

$\checkmark=$ Treatment

$\mathbf{x}=$ No treatment

including the time and duration of treatments within each TR, is provided in Table 1 .

\section{Trial layout}

The treated rootstock and scion material was placed separately in clean perforated plastic bags, one treatment per bag, in cold storage ( 1 to $2^{\circ} \mathrm{C}$ ) from June to the end of August, when grafting took place. The grafted cuttings from the various treatments were stacked in callusing boxes covered with fresh pine sawdust, one treatment per box, and allowed to callus for five weeks, following the standard methods for cold callusing followed by the specific nursery (Fourie \& Halleen, 2006a). After successful callusing, the graftlings were planted in two commercial field nurseries. The experiment was repeated the following season. However, due to the alternation between nursery blocks, the same nursery blocks could not be used (nursery A and B, 2006 to 2007; nursery H and I, 2007 to 2008). The experimental layout was a randomised block design with four blocks, $11 \mathrm{TR}$, and 50 graftlings/TR/block.

\section{Determination of growth parameters}

The nursery vines were uprooted at the end of a seven- to eightmonth growing season in May 2007 and 2008 respectively. The number of certifiable vines according to the standards of the Vine Improvement Association (PO Box 166, Paarl 7622 , South Africa) was determined as a percentage of the total number of grafted cuttings planted. The combined root and shoot mass of 25 randomly selected vines/TR/block was determined.

\section{Determination of infection levels}

The incidence of fungal pathogens in rootstock and scion cuttings was determined by means of destructive sampling before the cuttings were treated and placed in cold storage. Rootstock cuttings and grafts (100 of each) were collected from the nursery and taken to the laboratory for surface sterilisation $(30 \mathrm{~s}$ in $70 \%$ ethanol, $5 \mathrm{~min}$ in $0.35 \%$ sodium hypochlorite and $30 \mathrm{~s}$ in 70\% ethanol) before isolations were made. The canes were split lengthwise to reveal the xylem and pith regions. Eight pieces of xylem tissue (approximately $0.5 \times 1 \mathrm{~mm}$ in size) were aseptically removed from each cane and placed in Petri dishes containing 2\% potato dextrose agar (PDA, Biolab, Midrand, Johannesburg) amended with chloramphenicol $(250 \mathrm{mg} / \mathrm{L})$ to reduce bacterial growth (four pieces per dish). Dishes were incubated in an incubation growth room at $\pm 25^{\circ} \mathrm{C}$ and with a $12 \mathrm{~h}$ light, $12 \mathrm{~h}$ dark light regime. Fungal growth from plated tissue pieces was monitored daily for four weeks, identified based on colony and/or morphological characteristics as Trichoderma spp. (Rifai, 1969), Phaeoacremonium spp. (Mostert et al., 2006b), Pa. chlamydospora (Crous \& Gams, 2000), Pl. richardsiae (Vijaykrishna et al., 2004), Botryosphaeriaceae (Van Niekerk et al., 2004; Crous et al., 2006; Phillips et al., 2013) and black foot disease pathogens (Halleen et al., 2004; 2006; Lombard et al., 2014), or hyphal-tipped and transferred to PDA slants for later identification.

The incidence of fungal pathogens in the same 25 vines selected above for determination of growth parameters/ $\mathrm{TR} /$ block was also determined at the end of the sevento eight-month growing season by means of destructive sampling. Isolations from the roots, rootstocks (within $3 \mathrm{~cm}$ of the rootstock base) and graft unions, incubation and identification were done as described previously. Infection levels of Trichoderma spp. and grapevine trunk disease pathogens, viz. Pa. chlamydospora, Phaeoacremonium spp., $P l$. richardsiae, Botryosphaeriaceae and BFD pathogens, were calculated as a percentage of the eight dissected wood segments isolated from each plant zone.

\section{Statistical analyses}

Certifiable plant yield percentages, root and shoot mass, percentage pathogen and Trichoderma incidence data were subjected to analysis of variance using SAS version 8.1 (SAS Institute, Cary, North Carolina, USA). Student's t-least 
significant differences were calculated at the 5\% confidence level to compare treatment means

\section{RESULTS \\ Pathogen incidence in grafting material prior to cold storage}

Fungal pathogens, including Phaeoacremonium and Botryosphaeriaceae species, were isolated from $6 \%$ of both the rootstocks and scion cuttings during the 2006/2007 season, and from $8 \%$ of the rootstocks and $4 \%$ of the scions during 2007/2008.

\section{Growth parameters}

Percentage certifiable vines produced

Significant nursery $\times$ TR interaction was observed, and therefore the data for the four nursery blocks could not be combined ( $P=0.0003$; ANOVA not shown). This interaction was mainly caused by the extremely low take percentage (25\%) in the Thrichoflow regime (TR 4) and relatively high take percentage in an integrated regime (TR 11) $(72.2 \%)$ in Nursery H. This phenomenon was not observed in any of the other nurseries. Pre-grafting HWT (TR 6) also reduced the take percentages in Nursery H compared to the untreated controls (TR 7 and 8). However, this reduction also was not observed in any of the other nurseries. $\mathrm{CLO}_{2}$ and an integrated regime (TR 9) increased take percentages in Nursery I only. The percentage certifiable vines produced in the untreated controls (TR 7 and 8) was between $55.5 \%$ and $74.4 \%$. Compared to the untreated controls, none of the treatments consistently affected take percentages.

\section{Root mass}

The Trichoflow (31.7 g), Sporekill (31.5 g) and benomyl $(31.4 \mathrm{~g})$ treatments increased root mass significantly ( $P \geq 0.05$; ANOVA not shown). None of the other treatments differed from the untreated controls (TR 7 and 8, $27.6 \mathrm{~g}$ and $27.4 \mathrm{~g}$ respectively).

\section{Shoot mass}

Significant nursery $\times$ TR interaction was observed for shoot mass, and therefore data for the four nursery blocks could not be combined ( $P=0.0265$; ANOVA not shown). This interaction was caused by an increase in shoot mass caused by TR 4 in nursery $\mathrm{H}(32.9 \mathrm{~g})$ and TR 11 (17.7 g) in nursery I, compared to the untreated controls $(23.1 \mathrm{~g}$ and $21.2 \mathrm{~g}$ for TR 7 and 8 respectively in nursery $\mathrm{H}$, and $10.3 \mathrm{~g}$ and $12.8 \mathrm{~g}$ for TR 7 and 8 respectively in nursery I). This phenomenon was not observed in any of the other nurseries. Shoot mass for all 11 TR in Nursery $H$ was substantially higher (18.9 $\mathrm{g}$ to $32.9 \mathrm{~g}$ ) than the corresponding TR in the other three nurseries $(12.1 \mathrm{~g}$ to $15.4 \mathrm{~g}, 12.4 \mathrm{~g}$ to $16.4 \mathrm{~g}$ and $10.3 \mathrm{~g}$ to $17.7 \mathrm{~g}$ in nurseries A, B and I respectively). This might be due to differences in nursery practice, since nursery grapevines are pruned during the growing season. Except for TR 4 (nursery H) and TR 11 (nursery I), none of the other TR differed from the untreated controls (TR 7 and 8), and therefore it is concluded that none of the TR consistently affected shoot mass.

\section{Infection levels}

Phaeomoniella chlamydospora

Significant nursery $\mathrm{X}$ TR interaction $(P<0.0001$; ANOVA table not shown) was observed for the mean incidence in roots, and therefore the analyses for the four nurseries could not be combined. This interaction was mainly caused by a significantly higher incidence of $P a$. chlamydospora in the roots of TRs 4, 5 and 8 of nurseries A and B compared to nurseries $\mathrm{H}$ and I (Table 2). A higher incidence of $P a$. chlamydospora also occurred in TR 3 (nursery A) and TR 6 (nursery B) compared to the other nurseries. None of the treatments significantly increased the occurrence of $P a$. chlamydospora in nursery A, although TR 5 did not differ from TR 8, the untreated control. TRs 4, 3, 9, 1, 2, $6,7,10$ and 11 significantly reduced the incidence by $40 \%$, $52 \%, 96 \%, 100 \%, 100 \%, 100 \%, 100 \%, 100 \%$ and $100 \%$ respectively. None of the TRs significantly increased the incidence in Nursery B, although TR 4 and 5 did not differ from TR 8. Significant reductions were caused by TRs 6 (70\% reduction), 3 (96\%), 1, 2, 7, 9, 10 and 11 (all 100\%). TR 5 significantly increased the incidence in Nursery $H$, and TR 4, 6 and 10 did not differ from the untreated control. TRs 1, 2, 3, 7, 9 and 11 significantly reduced (100\%) the incidence. None of the TRs significantly increased the incidence in Nursery I, although TRs $1,3,4,5$ and 10 did not differ from the untreated control. TRs 2, 6, 7, 9 and 11 significantly reduced $(100 \%)$ the incidence. Significant nursery X TR interaction $(P<0.0001$; ANOVA not shown) was observed for the mean incidence in the basal ends of rootstocks, and therefore the analyses for the four nurseries could not be combined (Table 2). This interaction was caused mainly by TRs 1, 4 and 8. TR 4 and 5 significantly increased the incidence in nurseries $\mathrm{A}$ and $\mathrm{B}$ compared to TR 8. In nursery A, significant reductions were caused by TRs 3 (89\% reduction), 10, 6 (90\%), 1 (97\%), 7, 9 (98\%), 2 and $11(100 \%)$, while significant reductions were caused by TRs 10 (87\%), 3 (89\%), 6 (92\%), 9 (96\%), 2 (99\%), 1, 7, 11 $(100 \%)$ in nursery B. None of the TRs significantly increased the incidence in nurseries $\mathrm{H}$ and I, although TR 5 and 4 did not differ from TR 8 in Nurseries $H$ and I respectively. In nursery $\mathrm{H}$, significant reductions were caused by TRs 4 (42\%), 10 (86\%), 6 (90\%), 1 (94\%), 3 (96\%), 11 (98\%), $7(99 \%)$ and $2(100 \%)$, while significant reductions were caused by TRs 5 (9.7\%), 1 (74\%), 10 (80\%), 3 (81\%), 6, $11(98 \%), 2(99 \%)$ and $7(100 \%)$ in nursery I. Significant nursery $\mathrm{X}$ TR interaction ( $P=0.0004$; ANOVA not shown) was observed for the mean incidence in graft unions, and therefore the analyses for the four nurseries could not be combined (Table 2). This interaction was caused mainly by a higher incidence of $\mathrm{Pa}$. chlamydospora in TR 4 (nurseries A and $\mathrm{H}$ ), TR 8 (nurseries $\mathrm{H}$ and $\mathrm{I}$ ) and TR 10 (nursery $\mathrm{H}$ ), and a lower incidence of $\mathrm{Pa}$. chlamydospora in TR 5 (nursery I) compared to the other nurseries. TR 4 and 5 significantly increased the incidence in nursery A compared to in TR 8. None of the treatments caused an increase in any of the other nurseries, although TR 4 and 5 did not differ from TR 8 in nursery B, and TR 4 did not differ from TR 8 in nursery $\mathrm{H}$. TRs 1 (93 to $100 \%$ ), 2 (97 to $100 \%$ ), 3 (69 to $93 \%$ ), 6 ( 85 to $96 \%$ ), 7 (89 to $98 \%$ ), 9 (81 to $100 \%$ ), 10 (69 to $97 \%$ ) and 11 (98 to $100 \%$ ) significantly reduced the incidence compared 


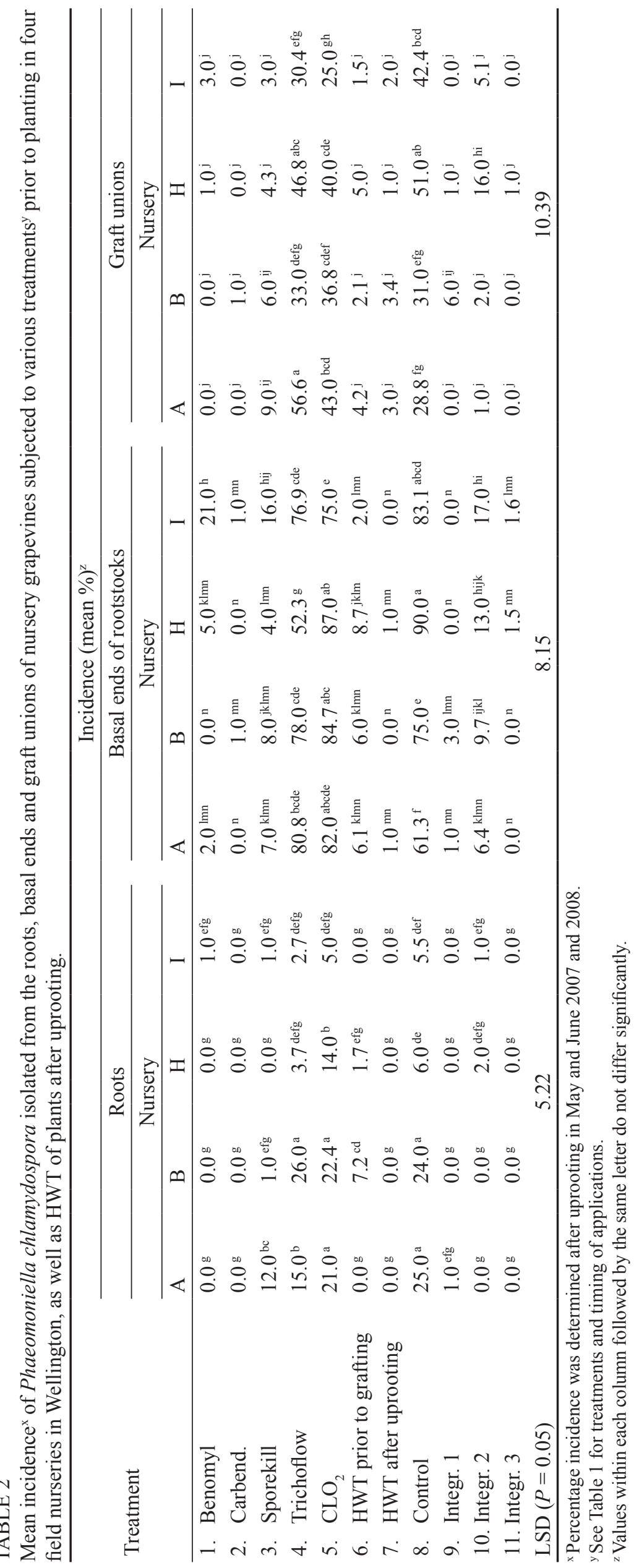


to TR 8 in all the nurseries, whilst TR 4 and 5 reduced infections in nursery I, and TR 5 only in nursery $\mathrm{H}$.

\section{Phaeoacremonium spp.}

No significant nursery $\mathrm{X}$ TR interaction $(P>0.05$; ANOVA not shown) was observed in any of the plant parts investigated, and therefore the analyses for the four nurseries could be combined (Table 3). Significant differences were observed between TRs for all the plant parts investigated $(P<0.0001)$. None of the treatments increased pathogen incidence in any of the plant parts (Table 3 ). The incidence in the roots in TRs 3, 4, 5 and 6 did not differ significantly from TR 8 (2.1\%), while TRs 7, 2, 10, 1, 9 and 11 significantly reduced the incidence, by 76.2 to $100 \%$, compared to TR 8 . The incidence in the basal ends of rootstocks in TRs 3, 4 and 5 did not differ significantly from TR 8 (4.7\%), while TRs $6,2,1,11,7,10$ and 9 significantly reduced the incidence, by 51 to $100 \%$, compared to TR 8 . In the graft unions, all the TRs significantly reduced the incidence compared to TR $8(10.2 \%)$. This reduction ranged between 36.3 and $97.5 \%$, with TR 7 being the best.

\section{Pleurostomophora richardsiae}

No significant nursery X TR interaction $(P>0.05$; ANOVA not shown) was observed and therefore the analyses for the four nurseries could be combined in the case of roots and basal ends, but not for the graft unions $(P<0.0001$; ANOVA not shown). Significant differences $(P=0.0414$; ANOVA not shown) were observed between the TRs in the roots, but this was only due to TR $6(0.9 \%$; Table 4$)$, which differed from TR $8(0 \%)$. None of the other TRs differed significantly from TR 8. No significant differences $(P=0.2586$; ANOVA not shown) were observed between the treatments in the basal ends of rootstocks, and none differed from TR $8(0.5 \%$; Table 4). The nursery X TR interaction in the graft unions was caused mainly by a significantly higher incidence in TR
$11(12.0 \%$; nursery I) compared to the other nurseries. The only reductions were observed in nursery A, where TRs 1,2 and 10 reduced the incidence compared to TR $8(6.0 \%)$. No TR showed an increased incidence in nursery A, although TR 3, 4, 5, 6, 7, 9 and 11 did not differ from TR 8. None of the treatments in nursery B differed from TR $8(4 \%)$. TR $10(8 \%)$ significantly increased the incidence in nursery $\mathrm{H}$ compared to TR 8 (2\%), but none of the other TRs differed from TR 8. TRs 6, 9, 10 and 11 significantly increased the incidence in nursery I compared to TR $8(1 \%)$, but none of the other treatments differed from TR 8 .

\section{BFD pathogens}

No significant nursery X TR interaction was observed, and therefore the analyses for the four nurseries could be combined in the case of roots $(P=0.1672$; ANOVA not shown), but not for the basal ends $(P=0.0555)$ and graft unions $(P=0.0004)$. Significant differences were observed between TRs in the roots ( $P=0.0014$; ANOVA not shown). TRs $6,11,9$ and 7 reduced the incidence by $44.4 \%, 49.4 \%$, $56.8 \%$ and $100 \%$ respectively compared to TR 8 , while TR 1, 2, 3, 4, 5 and 10 did not differ from TR 8 (Table 5). The nursery X TR interaction in the basal ends of rootstocks was caused mainly by the significantly higher incidence in TR 3 $(17.2 \%)$ in nursery $\mathrm{H}$ compared to the other nurseries. TR 1 , 2, 3 and 5 significantly increased the incidence in nursery $\mathrm{H}$ compared to TR $8(0 \%)$, although this was not observed in any of the other nurseries. TR $7(0 \%)$ significantly reduced the incidence in nursery A compared to the untreated control $(8.5 \%)$. None of the other treatments differed significantly from the untreated controls in nurseries $\mathrm{B}(3 \%), \mathrm{H}(0 \%)$ and I $(4.5 \%)$. The nursery $\mathrm{X}$ TR interaction in the graft unions was caused by TR 4 (nursery H) and TR 11 (nursery A), which caused a significantly higher incidence of BFD compared to the incidence in other nurseries. The incidence in all the nurseries was very low ( 0 to $3.9 \%$ ), and no TR significantly

TABLE 3

Mean incidence ${ }^{\mathrm{x}}$ of Phaeoacremonium spp. isolated from the roots, basal ends and graft unions of nursery grapevines subjected to various treatments ${ }^{y}$ prior to planting in four field nurseries in Wellington, as well as HWT of plants after uprooting.

\begin{tabular}{|c|c|c|c|}
\hline \multirow[b]{2}{*}{ Treatment } & \multicolumn{3}{|c|}{ Incidence $(\text { mean } \%)^{z}$} \\
\hline & Roots & Basal ends & Graft unions \\
\hline 1. Benomyl & $0.0^{\mathrm{c}}$ & $0.5^{\mathrm{de}}$ & $1.3^{\mathrm{de}}$ \\
\hline 2. Carbendazim & $0.3^{\mathrm{c}}$ & $1.0^{\text {cde }}$ & $1.0^{\mathrm{de}}$ \\
\hline 3. Sporekill & $2.7^{\mathrm{a}}$ & $2.8^{a b c}$ & $4.5^{b c}$ \\
\hline 4. Trichoflow & $2.7^{\mathrm{a}}$ & $3.6^{\mathrm{ab}}$ & $4.4^{\mathrm{bc}}$ \\
\hline 5. $\mathrm{CLO}_{2}$ & $2.8^{\mathrm{a}}$ & $3.8^{a b}$ & $6.5^{b}$ \\
\hline 6. Control (HWT prior to grafting) & $0.6^{\mathrm{bc}}$ & $2.3^{\mathrm{bcd}}$ & $3.3^{\mathrm{cd}}$ \\
\hline 7. Control (HWT after uprooting) & $0.5^{\mathrm{c}}$ & $0.0^{\mathrm{e}}$ & $0.3^{\mathrm{e}}$ \\
\hline 8. Control & $2.1^{a b}$ & $4.7^{\mathrm{a}}$ & $10.2^{\mathrm{a}}$ \\
\hline 9. Integrated 1 & $0.0^{\mathrm{c}}$ & $0.0^{\mathrm{e}}$ & $0.5^{\mathrm{e}}$ \\
\hline 10. Integrated 2 & $0.3^{\mathrm{c}}$ & $0.0^{\mathrm{e}}$ & $1.8^{\text {cde }}$ \\
\hline 11. Integrated 3 & $0.0^{\mathrm{c}}$ & $0.5^{\mathrm{de}}$ & $1.3^{\mathrm{de}}$ \\
\hline $\operatorname{LSD}(P=0.05)$ & 1.56 & 1.99 & 2.74 \\
\hline
\end{tabular}

${ }^{x}$ Percentage incidence was determined after uprooting in May and June 2007 and 2008.

${ }^{y}$ See Table 1 for treatments and timing of applications.

${ }^{z}$ Values within each column followed by the same letter do not differ significantly. 
TABLE 4

Mean incidence ${ }^{\mathrm{x}}$ of Pleurostomophora richardsiae isolated from the roots, basal ends and graft unions of nursery grapevines subjected to various treatments ${ }^{\mathrm{y}}$ prior to planting in four field nurseries in Wellington, as well as HWT of plants after uprooting.

\begin{tabular}{|c|c|c|c|c|c|c|}
\hline \multirow{3}{*}{ Treatment } & \multicolumn{6}{|c|}{ Incidence $(\text { mean } \%)^{\mathrm{z}}$} \\
\hline & \multirow[t]{2}{*}{ Roots } & \multirow[t]{2}{*}{ Basal ends } & \multicolumn{4}{|c|}{ Graft unions } \\
\hline & & & Nursery A & Nursery B & Nursery $\mathrm{H}$ & Nursery I \\
\hline 1. Benomyl & $0.0^{\mathrm{b}}$ & $0.0^{\mathrm{b}}$ & $0.0^{\mathrm{g}}$ & $0.0^{\mathrm{g}}$ & $0.0^{\mathrm{g}}$ & $0.0^{\mathrm{g}}$ \\
\hline 2. Carbendazim & $0.0^{\mathrm{b}}$ & $0.0^{\mathrm{b}}$ & $0.0^{\mathrm{g}}$ & $0.0^{\mathrm{g}}$ & $0.0^{\mathrm{g}}$ & $0.0^{\mathrm{g}}$ \\
\hline 3. Sporekill & $0.0^{\mathrm{b}}$ & $0.5^{\mathrm{ab}}$ & $10.0^{\mathrm{ab}}$ & $5.0^{\text {bcdefg }}$ & $2.0^{\mathrm{efg}}$ & $3.0^{\mathrm{defg}}$ \\
\hline 4. Trichoflow & $0.3^{\mathrm{b}}$ & $0.0^{\mathrm{b}}$ & $2.0^{\text {efg }}$ & $0.0^{\mathrm{g}}$ & $3.3^{\mathrm{defg}}$ & $2.9^{\mathrm{efg}}$ \\
\hline 5. $\mathrm{CLO}_{2}$ & $0.5^{\mathrm{ab}}$ & $1.3^{\mathrm{ab}}$ & $9.0^{\mathrm{abc}}$ & $5.0^{\text {bcdefg }}$ & $3.0^{\text {defg }}$ & $5.0^{\text {bcdefg }}$ \\
\hline 6. HWT prior to grafting & $0.9^{\mathrm{a}}$ & $1.6^{\mathrm{a}}$ & $3.6^{\mathrm{defg}}$ & $4.2^{\text {cdefg }}$ & $2.1^{\mathrm{efg}}$ & $6.9^{\text {bcde }}$ \\
\hline 7. HWT after uprooting & $0.0^{\mathrm{b}}$ & $0.3^{b}$ & $8.0^{\text {abcd }}$ & $4.4^{\text {cdefg }}$ & $7.0^{\text {abcde }}$ & $0.0^{\mathrm{g}}$ \\
\hline 8. Control & $0.0^{\mathrm{b}}$ & $0.5^{\mathrm{ab}}$ & $6.0^{\text {bcdef }}$ & $4.0^{\text {cdefg }}$ & $2.0^{\mathrm{efg}}$ & $1.0^{\mathrm{fg}}$ \\
\hline 9. Integrated 1 & $0.0^{\mathrm{b}}$ & $0.8^{\mathrm{ab}}$ & $1.0^{\mathrm{fg}}$ & $2.0^{\mathrm{efg}}$ & $6.0^{\text {bcdef }}$ & $8.0^{\mathrm{abcd}}$ \\
\hline 10. Integrated 2 & $0.0^{\mathrm{b}}$ & $0.0^{\mathrm{b}}$ & $0.0^{\mathrm{g}}$ & $2.0^{\mathrm{efg}}$ & $8.0^{\mathrm{abcd}}$ & $6.1^{\text {bcde }}$ \\
\hline 11. Integrated 3 & $0.0^{\mathrm{b}}$ & $0.5^{\mathrm{ab}}$ & $5.2^{\text {bcdef }}$ & $0.0^{\mathrm{g}}$ & $2.0^{\mathrm{efg}}$ & $12.0^{\mathrm{a}}$ \\
\hline $\operatorname{LSD}(P=0.05)$ & 0.59 & 1.35 & \multicolumn{4}{|c|}{5.08} \\
\hline
\end{tabular}

${ }^{x}$ Percentage incidence was determined after uprooting in May and June 2007 and 2008.

${ }^{y}$ See Table 1 for treatments and timing of applications.

${ }^{z}$ Values within each column followed by the same letter do not differ significantly.

reduced the incidence. TR 9 and 11 significantly increased the incidence in nursery A compared to TR $8(0 \%)$, while TR 4 increased the incidence in nursery $\mathrm{H}$. None of the other TR in any of the other nurseries differed significantly from TR 8.

\section{Botryosphaeriaceae spp.}

No significant ( $P>0.05$; ANOVA not shown) nursery $\mathrm{X}$ TR interaction was observed in any of the plant parts investigated, and therefore the analyses for the four nurseries could be combined. No Botryosphaeriaceae spp. were found in the roots. No significant differences $(P=0.7334$; ANOVA not shown) were observed between TRs in the basal ends of the rootstocks, and none differed from the untreated control $(0 \%$; data not shown). Significant differences $(P<0.0001$; ANOVA not shown) were observed between TRs in the graft unions, and all TRs differed from the untreated control (4.9\%; data not shown in a table). Compared to the untreated control, TRs 3, 4, 5, 1, 6, 11, 2, 7, 9 and 10 reduced the incidence significantly, by 43 to $94 \%$.

\section{Trichoderma spp.}

No significant nursery X TR interaction was observed, and therefore the analyses for the four nurseries could be combined in the case of the roots and graft unions $(P>0.05$; ANOVA not shown), but not for the basal ends $(P<0.0001)$. No significant differences $(P=0.5519$; ANOVA not shown) were observed between TRs in the roots, and none differed from the untreated control $(0 \%)$. The nursery X TR interaction in the basal ends of rootstocks was caused by TR 4 , since a significantly higher incidence occurred in nurseries $\mathrm{H}$ and I compared to nurseries $\mathrm{A}$ and $\mathrm{B}$. The incidence of Trichoderma was significantly more in TR 4 in all the nurseries compared to TR 8. The other TR that received Trichoderma (TR 9, 10 and 11) did not differ significantly from TR 8. Significant differences were observed between TRs in the graft unions $(P<0.0001$; ANOVA not shown). The incidence in all the TRs that received Trichoderma (TRs 4, 9, 10 and 11) differed significantly from the untreated control ( $0 \%)$. Furthermore, the Trichoderma incidence in TR $4(9.3 \%)$ was also significantly more than in TR $9(6.5 \%), 10$ $(5.1 \%)$ and $11(3 \%)$.

\section{DISCUSSION}

The aim of the current study was to evaluate and compare 11 treatment regimes (TR) that differed with regard to their compliance with good agricultural practice. Some of the treatments used in this study have been tested before and their efficacy has been proven. Treatments therefore were not evaluated in all the combinations in which they could be applied during the various stages in the propagation process. The treatments were classified as "red", "orange" and "green", with red being the least environmentally friendly (although effective), orange being more environmentally friendly with certain precautions to be undertaken, and green being the most environmentally friendly. The red treatments included benomyl and carbedazim. Dimethyldidecylammonium chloride, a quaternary ammonium compound used as a sterilising agent, represented orange. Dimethyldidecylammonium chloride is toxic to fish and therefore is regarded as environmentally unfriendly if the wastewater is discarded in rivers or dams. However, if the wastewater can be discarded in a temporary soil dam (without aquatic life), the active ingredient would be able to bind to soil particles and break down over time. Alternatively, the wastewater could be treated with kaolin, which would bind the active, ingredient making it harmless. Trichoflow-T ${ }^{\mathrm{TM}}$ and chlorine dioxide represented the green treatments. $\mathrm{CLO}_{2}$ is used in many industries as a disinfectant, for example to sanitise fruit and vegetables and to disinfect 


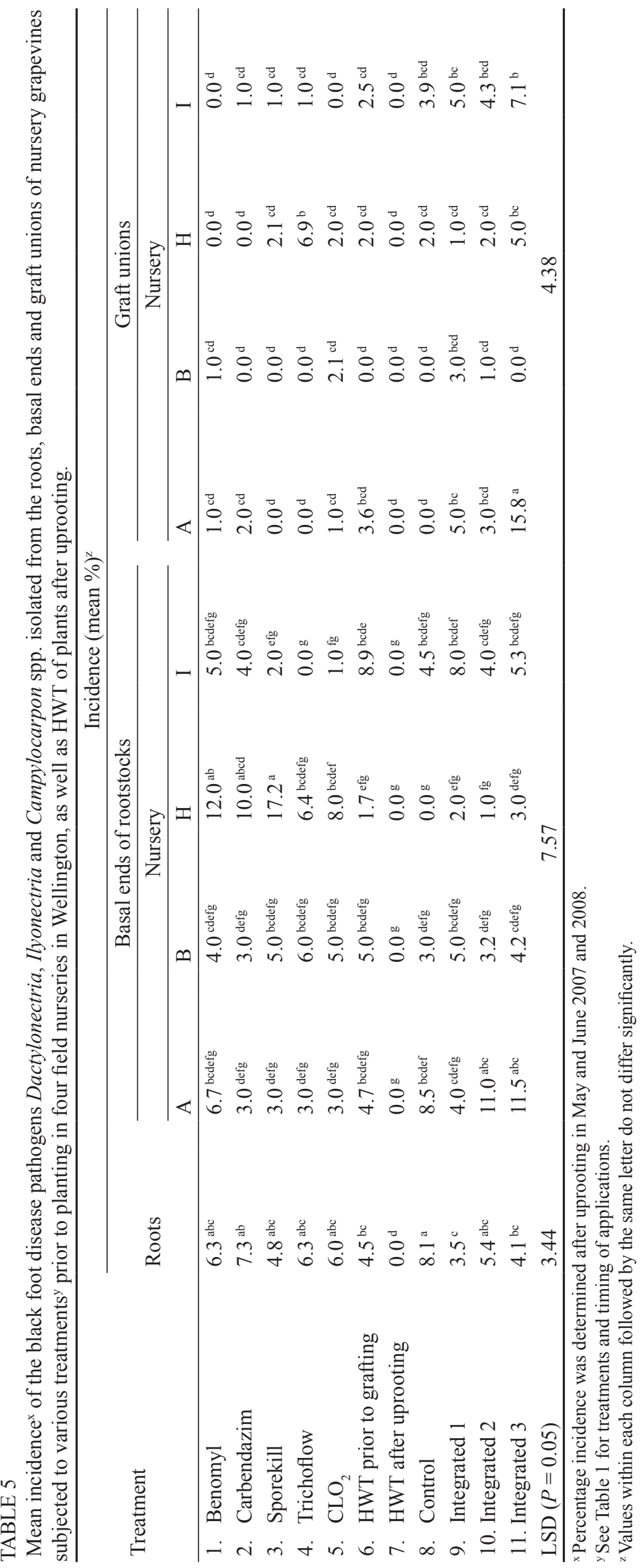


drinking water.

None of the TRs affected growth parameters consistently, although TR 4 (Trichoflow), TR 3 (Sporekill) and TR 1 (Benomyl) significantly increased root mass, again showing the growth-stimulating effect of Trichoderma.

Phaeomoniella chlamydospora was by far the most frequently isolated pathogen on all the plant parts investigated. A grapevine can become infected by this pathogen from various sources throughout its lifetime (Mostert et al., 2006c), and it therefore is of the utmost importance to prevent these infections during the propagation process. In general, TRs 4 and 5 either increased the incidence of $P$ a. chlamydospora, did not differ from the untreated control, or the reductions were not sufficient enough to be regarded as effective. TRs 2, 7, 9 and 11 consistently caused the lowest incidence of $P a$. chlamydospora in all the plant parts, although TR 6 also reduced it. Phaeoacremonium spp. occurred in all the plant parts, although the highest incidence was recorded in the graft unions. The most consistent result was obtained with TR 9, which reduced the incidence of Phaeoacremonium spp. in all the plant parts, although TR 7 also was effective. The incidence of Pleurostomophora richardsiae mostly was very low, especially in the roots and basal ends, and therefore it is very difficult to draw meaningful conclusions. The highest incidence occurred in the graft union, and it is interesting to note that the only reductions were observed in the nursery in which the highest incidence occurred in the untreated control. TRs 1, 2 and 10 reduced the incidence. However, TR 10 was inconsistent, since it increased the incidence in one nursery and did not differ from TR 8 in another. The fact that TR 7 (HWT of dormant vines) could not reduce these infections is a significant finding. Recent studies have shown that some Phaeoacremonium species have a higher temperature tolerance than the standard HWT regime of $50^{\circ} \mathrm{C}$ for $30 \mathrm{~min}$ (Gramaje et al., 2008; 2010), and it might be necessary to investigate this phenomenon in $P l$. richardsiae. BFD pathogens occurred most frequently in the roots, followed by the rootstock and, to a lesser extent, in the graft unions. TR 7 was the most consistent and by far the best TR, since it completely eradicated or kept infections at $0 \%$. This result is in line with previous findings (Halleen et al., 2007b). None of the other TRs consistently reduced infections or caused reductions that could be regarded as effective. No Botryosphaeriaceae spp. were found in the roots, and their incidence was very low in the basal ends. The highest incidence occurred in the graft unions, and there all the TRs significantly reduced infection. None of the treatments increased the incidence of Botryosphaeriaceae spp. in any of the plant parts.

Colonisation of the basal ends and graft unions by Trichoderma was significantly better with TR 4, although the other TRs that received Trichoderma (TR 9, 10 and 11) also colonised the graft unions. The fact that Trichoderma were not found in the roots to the same extent as in the rootstocks and graft unions is understandable, since there were no roots prior to planting, or those grafted cuttings that had callus roots broke off once taken out of the callus boxes or when planted. TR 11, an experimental treatment in which the graft unions were not waxed after grafting, was included in this study to determine whether Trichoderma would be able to colonise the graft unions better. However, better Trichoderma colonisation was not obtained. In fact, Trichoderma colonisation was significantly better in TR 9, which received wax, as well as TR 4.

TRs 1 and 2, the least environmentally friendly regimes, significantly reduced the incidence of $\mathrm{Pa}$. chlamydospora, Pl. richardsiae, Phaeoacremonium and Botryosphaeriaceae spp., although it could not reduce BFD pathogens. TRs 1 and 2 were equally effective against all the pathogens, except in one instance, where TR 1 significantly increased the incidence of $\mathrm{Pa}$. chlamydospora. Carbendazim therefore could replace benomyl, which currently is recommended for use in South African nurseries (Fourie \& Halleen, 2006a) when the latter is no longer available. In general, the more environmentally friendly TR 3 was equally as effective as TRs 1 and 2 in reducing $P a$. chlamydospora, but was less effective against Phaeoacremonium and Botryosphaeriaceae and had no effect on $P l$. richardsiae and BFD pathogens. TRs 4 and 5, the most environmentally friendly regimes, either increased the incidence of Pa. chlamydospora, did not differ from the untreated controls, or did not reduce the incidence enough. It reduced the incidence of Phaeoacremonium and Botryosphaeriaceae spp. to some extent, but had no effect on Pleurostomophora richardsiae and BFD pathogens, or increased incidences of the latter. The importance of HWT of all propagation material prior to grafting (TR 6) was clearly illustrated. TR 6 was as effective as TR 1 in reducing the incidence of $\mathrm{Pa}$. chlamydospora, Botryosphaeriaceae and Phaeoacremonium spp., although TR 9, the TR in which HWT is integrated with various other treatments, reduced the incidence of Phaeoacremonium spp. even more. Furthermore, although TRs 9 and 10 were equally effective against most pathogens, TR 9 was more consistent in reducing Pa. chlamydospora than TR 10, the TR without HWT. TR 9 significantly reduced the incidence of Pa. chlamydospora, Phaeoacremonium and Botryosphaeriaceae, and even reduced the incidence of BFD pathogen in the roots.

The treatment of propagation material at various stages throughout the propagation process, following an integrated strategy, therefore is more effective in reducing the incidence of the entire spectrum of trunk disease pathogens. Trichoderma performed better in the integrated strategies than in repeat treatments of the same product. The reason why repeated Trichoderma applications in some instances increased the incidence of Pa. chlamydospora is not known. This phenomenon might be caused by an activation of the host response due to stimulation by Trichoderma. However, the incidence of Trichoderma in all the plant parts was very low and therefore the mere presence of Trichoderma might not be the cause. Fourie and Halleen (2006a) also reported negative effects (lower certifiable plant yields) in certain situations when Trichoderma was applied as repeated drenches. It is a well-known fact that Trichoderma produces a large number of secondary metabolites with biological activity (Vinale et al., 2008). The compound 6-pentyl-apyrone (6PP) has been identified as the major secondary metabolite produced by Trichoderma species used for the control of grapevine trunk diseases (Mutawila et al., 2016). Plant genes respond to pathogens and elicitors. For this reason, plant defence mechanisms do not necessarily 
require stimulation by the living organism. The addition of Trichoderma metabolites that may act as elicitors of plant resistance also results in the synthesis of phytoalexins, pathogenesis-related proteins and other compounds, and in an increase in resistance against several plant pathogens (Benítez et al., 2004). During the interaction of Trichoderma with the plant, different classes of metabolites may act as elicitors or resistance inducers (Vinale et al., 2008). Phenolic compounds like tannins, phenolic acids, flavanoids and stilbenes are phytoalexins of the grapevine (Del Rio et al., 2004). However, in the case of already infected grapevine material, an activation of a host response might also activate latent $\mathrm{Pa}$. chlamydospora infections. Calzarano et al. (2007) found that frequent spraying of foliar fertilisers and bioactivators on esca-affected plants during the growing season increased the incidence and severity of disease. Di Marco and Osti (2009) also observed an increase in esca-affected vines after the vines were sprayed with biostimulants. Martin et al. (2009) identified trans-resveratrol and $\epsilon$-viniferen and observed an increase in total phenolic content and trans-resveratrol in uncolonised tissue upon increased accumulation of phenolic compounds following fungal colonisation. However, $\mathrm{Pa}$. chlamydospora is able to grow in the presence of resveratrol and tannic acid (Martin et al., 2009) and has the ability to degrade resveratrol (Bruno \& Sparapano, 2006). $\mathrm{CLO}_{2}$ also increased the incidence of $P a$. chlamydospora in some instances, and this also might be due to an activation of host response.

HWT of dormant vines (TR 7) is highly recommended to eradicate BFD pathogens. It also significantly reduced the incidence of $\mathrm{Pa}$. chlamydospora, Phaeoacremonium and Botryosphaeriaceae. It is recommended that benomyl be replaced with carbendazim when benomyl is no longer available. Carbendazim as a soak treatment during the hydration stage was also found to be effective against Petri disease fungi in Spanish nurseries (Gramaje et al., 2009). TR 9 is recommended as an integrated strategy for the proactive management of grapevine trunk diseases in nurseries.

\section{LITERATURE CITED}

Agustí-Brisach, C., Gramaje, D., García-Jiménez, J. \& Armengol, J., 2013. Detection of black-foot disease pathogens in the grapevine nursery propagation process in Spain. Eur. J. Plant Pathol. 137, 103-112.

Aroca, Á., Gramaje, D., Armengol, J., García-Jiménez, J. \& Raposo, R., 2010. Evaluation of the grapevine nursery propagation process as a source of Phaeoacremonium spp. and Phaeomoniella chlamydospora and occurrence of trunk disease pathogens in rootstock mother vines in Spain. Eur. J. Plant Pathol. 126, 165-174.

Benítez, T., Rincón, A.M., Limón, M.C. \& Codón, A.C., 2004. Biocontrol mechanisms of Trichoderma strains. Int. Microbiol. 7, 249-260.

Bester, W., Crous, P.W. \& Fourie, P.H., 2007. Evaluation of fungicides as potential grapevine pruning wound protectants against Botryosphaeria species. Australas. Plant Pathol. 36, 73-77.

Bruno, G. \& Sparapano, L., 2006. Effects of three esca-associated fungi on Vitis vinifera L: III. Enzymes produced by the pathogens and their role in fungus-to-plant or in fungus-to-fungus interactions. Physiol. Mol. Plant P. 69, 182-194.

Calzarano, F., Amalfitano, C., Seghetti, L. \& D’Agostino, V., 2007. Foliar treatment of esca-proper affected vines with nutrients and bioactivators. Phytopathol. Mediterr. 46, 207-217.
Carlucci, A., Cibelli, F., Lops, F., Phillips, A.J.L., Ciccarone, C. \& Raimondo, M.L., 2015. Pleurostomophora richardsiae associated with trunk diseases of grapevines in southern Italy. Phytopathol. Mediterr. 54, 109-123.

Crous, P.W. \& Gams, W., 2000. Phaeomoniella chlamydospora gen. et comb. nov., a casual organism of Petri grapevine decline and esca. Phytopathol. Mediterr. 39, 112-118.

Crous, P.W., Slippers, B., Wingfield, M.J., Rheeder, J., Marasas, W.F.O., Phillips, A.J.L., Alves, A., Burgess, T., Barber, P. \& Groenewald, J.Z., 2006. Phylogenetic lineages in the Botryosphaeriaceae. Stud. Mycol. 55, 235-253.

Del Rio, J.A., Gómez, P., Báidez, M.D., Fuster, M.D., Ortuño, A. \& Frias, V., 2004. Phenolic compounds have a role in the defence mechanism protecting grapevine against the fungi involved with Petri disease. Phytopathol. Mediterr. 43, 87-94.

Di Marco, S. \& Osti, F., 2009. Effect of biostimulant sprays on Phaeomoniella chlamydospora and esca proper infected vines under greenhouse and field conditions. Phytopathol. Mediterr. 48, 47-58.

Ferreira, J.H.S., Van Wyk, P.S. \& Calitz, F.J., 1999. Slow dieback of grapevine in South Africa: Stress-related predisposition of young vines for infection by Phaeoacremonium chlamydosporum. S. Afr. J. Enol. Vitic. $20(2), 43-46$

Fourie, P.H. \& Halleen, F., 2002. Investigation on the occurrence of Phaeomoniella chlamydospora in canes of rootstock mother vines. Australas. Plant Path. 31, 425-426.

Fourie, P.H. \& Halleen, F., 2004a. Proactive control of petri disease of grapevine through treatment of propagation material. Plant Dis. 88, 12411245.

Fourie, P.H. \& Halleen, F., 2004b. Occurrence of grapevine trunk disease pathogens in rootstock mother plants in South Africa. Australas. Plant Pathol. 33, 313-315.

Fourie, P.H. \& Halleen, F., 2006a. Chemical and biological protection of grapevine propagation material from trunk disease pathogens. Eur. J. Plant Pathol. 116, 255-265.

Fourie, P.H. \& Halleen, F., 2006b. Sanitary control measures against trunk disease pathogens in grapevine nurseries. Wynboer 206, 80-82.

Fourie, P.H., Halleen, F., Van der Vyver, F. \& Schreuder, W., 2001. Effect of Trichoderma treatments on the occurrence of decline pathogens in the roots and rootstocks of nursery grapevines. Phytopathol. Mediterr. 40(Suppl.), S473-S478.

Gramaje, D. \& Armengol, J., 2011. Fungal trunk pathogens in the grapevine propagation process: Potential inoculum sources, detection, identification, and management strategies. Plant Dis. 95, 1040-1055.

Gramaje, D., Aroca, A., Rapaso, R., García-Jiménez, J. \& Armengol, J., 2009. Evaluation of fungicides to control Petri disease pathogens in the grapevine propagation process. Crop Prot. 28, 1091-1097.

Gramaje, D., Alaniz, S., Abad-Campos, P., García-Jiménez, J. \& Armengol, J., 2010. Effect of hot-water treatments in vitro on conidial germination and mycelial growth of grapevine trunk pathogens. An. Appl. Biol. 156, 231-241.

Gramaje, D., García-Jiménez, J. \& Armengol, J., 2008. Sensitivity of Petri disease pathogens to hot-water treatments in vitro. An. Appl. Biol. 153, 95103.

Halleen, F. \& Groenewald, M., 2005. Grapevine diagnostic observations with special reference to trunk diseases. In: Innovations for sustainable plant health. Proc. 15th Biennial Australas. Plant Path. Soc. Conf., September, Geelong, Australia.

Halleen, F., Crous, P.W. \& Petrini, O., 2003. Fungi associated with healthy grapevine cuttings in nurseries, with special reference to pathogens involved in the decline of young vines. Australas. Plant Pathol. 32, 47-52. 
Halleen, F., Fourie, P.H. \& Crous, P.W., 2005. A review of black foot disease of grapevine. Phytopathol. Mediterr. 45(Suppl.), S55-S67.

Halleen, F., Fourie, P.H. \& Crous, P.W., 2007b. Control of black foot disease in grapevine nurseries. Plant Pathol. 56, 637-645.

Halleen, F., Mostert, L. \&. Crous, P.W., 2007a. Pathogenicity testing of lesser known vascular fungi of grapevines. Australas. Plant Pathol. 36, $277-$ 285 .

Halleen, F., Schroers, H.J., Groenewald, J.Z. \& Crous, P.W., 2004. Novel species of Cylindrocarpon (Neonectria) and Campylocarpon gen. nov. associated with black foot disease of grapevines (Vitis spp.). Stud. Mycol. $50,431-455$

Halleen, F., Schroers, H.J., Groenewald, J.Z., Rego, C., Oliveira, H. \& Crous, P.W., 2006. Neonectria liriodendri sp. nov., the main causal agent of black foot disease of grapevines. Stud. Mycol. 55, 227-234.

Jaspers, M.V., 2001. Effect of fungicides, in vitro, on germination and growth of Phaeomoniella chlamydospora. Phytopathol. Mediterr. 40(Suppl.), S453-S458.

Khan, A., Whiting, C., Rooney, S. \& Gubler, W.D., 2000. Pathogenicity of three species of Phaeoacremonium spp. on grapevine in California. Phytopathol. Mediterr. 39, 92-99.

Kotze, C., Van Niekerk, J., Mostert, L., Halleen, F. \& Fourie, P., 2011. Evaluation of biocontrol agents for grapevine pruning wound protection against trunk pathogen infection. Phytopathol. Mediterr. 50(Suppl.), S247-S263.

Lombard, L., Van der Merwe, N., Groenewald, J.Z. \& Crous, P.W., 2014. Lineages in Nectriaceae: Re-evaluating the generic status of Ilyonectria and allied genera. Phytopathol. Mediterr. 53, 515-532.

Martin, N., Vesentini, D., Rego, C., Monteiro, S., Oliveira, H. \& Ferreira, R.B., 2009. Phaeomoniella chlamydospora infection induces changes in phenolic compounds content in Vitis vinifera. Phytopathol. Mediterr. 48, 101-116.

Mostert, L., Abeln, E.C.A., Halleen, F. \& Crous, P.W., 2006c. Genetic diversity among isolates of Phaeomoniella chlamydospora on grapevines. Australas. Plant Path. 35, 453-460.

Mostert, L., Groenewald, J.Z., Gams, W., Summerbell, R.C. \& Crous, P.W., 2006b. Taxonomy and pathology of Togninia (Diaporthales) and its Phaeoacremonium anamorphs. Stud. Mycol. 54, 1-115.

Mostert, L., Halleen, F., Fourie, P.H. \& Crous, P.W., 2006a. A review of Phaeoacremonium species involved in Petri disease and esca of grapevines. Phytopathol. Mediterr. (Suppl.) 45, S12-S29.

Mutawila, C., Fourie, P.H., Halleen, F. \& Mostert, L., 2011. Histopathology study of the growth of Trichoderma harzianum, Phaeomoniella chlamydospora and Eutypa lata on grapevine pruning wounds. Phytopathol. Mediterr. 50(Suppl.), S46-S60.
Mutawila, C., Vinale, F., Halleen, F., Lorito, M. \& Mostert, L., 2016. Isolation, production and in vitro effects of the major secondary metabolite produced by Trichoderma species used for the control of grapevine trunk diseases. Plant Pathol. 65, 104-113.

Phillips, A.J.L., Alves, A., Abdollahzadeh, J., Slippers, B., Wingfield, M.J., Groenewald, J.Z. \& Crous, P.W., 2013. The Botryosphaeriaceae: Genera and species known from culture. Stud. Mycol. 76, 51-167.

Retief, E., McLeod, A. \& Fourie, P.H., 2006. Potential inoculum sources of Phaeomoniella chlamydospora in South African grapevine nurseries. Eur. J. Plant Pathol. 115, 331-339.

Rifai, M.A., 1969. A revision of the genus Trichoderma. Mycol. Papers 116, $1-56$.

Scheck, H.J., Vasquez, S.J., Fogle, D. \& Gubler, W.D., 1998a. Grape growers report losses to black foot and grapevine decline. Calif. Agr. 52, $19-23$

Scheck, H.J., Vasquez, S.J., Gubler, W.D. \& Fogle, D., 1998b. First report of black-foot disease caused by Cylindrocarpon obtusisporum of grapevines in California. Plant Dis. 82, 448 .

Sparapano, L., De Leonardis, S., Campanella, A. \& Bruno, G. 2001. Interaction between esca-associated fungi, grapevine calli and micropropagated shoot cultures of grapevine. Phytopathol. Mediterr. 40, $35-43$.

Van Niekerk, J.M., Bester, W., Halleen, F., Crous, P.W. \& Fourie, P.H., 2010. First record of Lasiodiplodia crassispora as a pathogen of grapevine trunks in South Africa. Plant Dis. 94(8), 1063.

Van Niekerk, J.M., Crous, P.W., Groenewald, J.Z., Fourie, P.H. \& Halleen, F., 2004. DNA phylogeny, morphology and pathogenicity of Botryosphaeria species on grapevines. Mycologia 96(4), 781-798.

Van Niekerk, J.M., Fourie, P.H., Halleen, F. \& Crous, P.W., 2006. Botryosphaeria spp. as grapevine trunk disease pathogens. Phytopathol. Mediterr. 45(Suppl.), S43-S54

Van Niekerk, J.M., Strever, A., Du Toit, P.G., Halleen, F. \& Fourie, P.H., 2011. Influence of water stress on Botryosphaeriaceae disease expression in grapevines. Phytopathol. Mediterr. 50(Suppl.), S151-S165.

Vijaykrishna, D., Mostert, L., Jeewon, R., Gams, W., Hyde, K.D. \& Crous, P.W., 2004. Pleurostomophora, an anamorph of Pleurostoma (Calosphaeriales), a new anamorph genus morphologically similar to Phialophora. Stud. Mycol. 50, 387-396.

Vinale, F., Sivasithamparam, K., Ghisalberti, E.L., Marra, R., Woo, S.L. \& Lorito, M., 2008. Trichoderma-plant-pathogen interactions. Soil Biol. Biochem. 40, 1-10.

Wallace, J., Edwards, J., Pascoe, I.G. \& May, P., 2003. Phaeomoniella chlamydospora inhibits callus formation by grapevine rootstock and scion cultivars. In: 3rd International Workshop on Grapevine Trunk Diseases, Lincoln, New Zealand. Page 24 